\title{
Normal folic acid metabolism in iron-deficient rats
}

\author{
By D. G. BURNS AND G. H. SPRAY \\ Nuffield Department of Clinical Medicine, Radcliffe Infirmary, Oxford
}

(Received 6 January 1969-Accepted 6 February 1969)

\begin{abstract}
I. Weanling rats were fed on an iron-deficient diet without added folic acid and litter-mate controls received the same diet supplemented with Fe. Groups of deficient and control animals were killed at intervals of up to 88 days and glutamate formiminotransferase activity in liver and folic acid activity in liver and serum were measured.

2. No differences were found between the results from the deficient and control animals, although the deficient diet produced marked falls in haemoglobin, packed cell volume and serum iron.

3. In a second experiment folic acid was added to the diets and twelve rats received the Fe-deficient diet and their litter-mates were fed on the Fe-supplemented diet for 91 days. No differences were found in the activity of glutamate formiminotransferase purified from the combined livers of the two groups.
\end{abstract}

Iron deficiency has been reported to affect folic acid metabolism in pregnant women (Chanarin, Rothman \& Berry, 1965), patients with hookworm infection (Velez, Restrepo, Vitale \& Hellerstein, 1966) and rats (Vitale, Streiff \& Hellerstein, 1965; Vitale, Restrepo, Velez, Riker \& Hellerstein, r966). Conversely, addition of folic acid and choline to a diet which, when not supplemented, produced haemochromatosis in rats prevented the deposition of excess Fe (MacDonald, Jones \& Pechet, 1965). Fe-deficient rats showed decreased activity of glutamate formiminotransferase, (EC2 I I 2.5: $N$-formimino-L-glutamate:tetrahydrofolate 5 -formiminotransferase) isolated from liver, increased urinary excretion of folic acid and formiminoglutamic acid (Vitale et al. 1965, 1966) and, in one report (Vitale et al. 1966), decreased levels of folic acid in serum. This paper describes similar experiments, which gave results conflicting with previous reports.

\section{EXPERIMENTAL}

Animals and diets. Female weanling Wistar rats, from Allington Farm, Porton Down, Salisbury, Wilts., were kept in Perspex cages with aluminium mesh floors and tops, in groups selected to contain equal numbers of animals from each litter. In the first experiment one group was fed on an Fe-deficient diet prepared as described by McCall, Newman, O'Brien, Valberg \& Witts (1962) except that folic acid was omitted; the other group received the same diet supplemented with $240 \mathrm{mg} \mathrm{Fe} / \mathrm{kg}$. In the second experiment folic acid ( $\mathrm{I} \mathrm{mg} / \mathrm{kg}$ ) was added to the diets because Vitale et al. (1965, 1966) used diets containing this supplement. Food and water were given $a d$ lib. and the rats were weighed twice weekly.

Expt I. Eight Fe-deficient rats and eight litter-mate controls were killed at the start of the experiment and after I4, 28, 42 and 88 days. Granulocyte counts were made after 20 days on blood from the tail vein in those rats that were to be killed at 
28 days and after 33 days in those selected for killing at 42 days. Before killing, haemoglobin and packed cell volume were measured and blood films prepared with blood from the tail vein. The rats were then anaesthetized with ether, bone marrow was obtained from the upper femur (Cameron \& Watson, 1948) in the animals killed after I4, 28 and 42 days and the rats were killed by bleeding from the dorsal aorta. Serum for determination of $\mathrm{Fe}$ or folic acid activity was separated from the blood. The livers were rapidly removed, washed with cold distilled water, blotted and immediately frozen and stored at $-18^{\circ}$ until the glutamate formiminotransferase and folic acid activities were measured.

Expt 2. Twelve rats were fed on the Fe-deficient diet and their litter-mates on the iron-supplemented diet for $9 \mathrm{I}$ days. The livers from each group were combined and acetone powders were prepared and glutamate formiminotransferase was purified from the powders, by the methods of Tabor $\&$ Wyngarden (1958). At each stage of purification the activity of the enzyme was measured, and protein was determined in the solutions by measuring the absorption at $280 \mathrm{~nm}$ and $260 \mathrm{~nm}$ in a Unicam $\mathrm{SP}_{500}$ spectrophotometer (Layne, 1957).

Determination of glutamate formiminotransferase. The enzyme was determined in the first experiment in crude liver homogenates and, in the second experiment, in the solutions obtained during the purification, by a modification of the method of Tabor \& Wyngarden (1959). Livers were thawed at room temperature and $0.5 \mathrm{~g}$ was homogenized with $3 \mathrm{ml} 0^{\circ} \cdot \mathrm{I}$ M-potassium phosphate buffer, $\mathrm{pH} 7^{\circ} \circ$, in a tissue grinder. The mixtures were stored at $-\mathrm{I} 8^{\circ}$ for up to 5 days. Sodium formiminoglutamate was prepared by adding $\mathrm{Na}_{2} \mathrm{SO}_{4}$ solution to a solution of the barium salt (Sigma Chemical Co.). Tetrahydropteroylglutamic acid was synthesized (O'Dell, Vandenbelt, Bloom \& Pfiffner, 1947) and stored under hydrogen at $-18^{\circ}$ in $0^{\circ} \mathrm{I}$ M-potassium phosphate buffer, $\mathrm{pH} 7 \cdot 0$, containing $0.2 \mathrm{M}$-mercaptoethanol.

Homogenates were diluted four times with buffer. Diluted homogenate $(0 \cdot 1 \mathrm{ml})$ or $0 . \mathrm{Iml}$ of suitable dilutions of the partially purified enzyme solutions, was mixed with $0.1 \mathrm{ml} \mathrm{M}$-potassium phosphate buffer, $\mathrm{pH} 7.2,0.1 \mathrm{ml} 0.005$ M-tetrahydropteroylglutamic acid solution, $0.05 \mathrm{ml}$. I $\mathrm{M}$-sodium formiminoglutamate solution and $0.95 \mathrm{ml}$ water at $25^{\circ}$. After $2 \mathrm{~min}, 0.3 \mathrm{ml} 10 \%$ (w/v) perchloric acid solution was added, the mixture was heated at $100^{\circ}$ for $50 \mathrm{sec}$, cooled in ice and centrifuged. The clear supernatant solution was decanted and 5,10-methenyl tetrahydropteroylglutamic acid was determined by measuring the absorption at $35^{\circ} \mathrm{nm}$ in a Hilger Uvispek spectrophotometer or a Unicam SP 500 spectrophotometer, against a blank from which formiminoglutamate had been omitted. Estimations were carried out in duplicate. The results were expressed in units/g wet liver or, in Expt 2, units/mg protein; one unit was the activity that transformed I $\mu$-mole of substrate at $25^{\circ}$.

Determination of folic acid activity. Folic acid was determined by microbiological assay with Lactobacillus casei (Spray, 1964). Serum was extracted in the same way as human serum except that $0.2 \mathrm{M}$-sodium phosphate buffer, $\mathrm{pH} 5 \cdot 6$, instead of $\mathrm{pH} 6 \cdot \mathrm{I}$, was necessary in order to obtain clear extracts. Liver homogenates were prepared and incubated as described by Bennett, Berry, Chanarin \& Ardeman (1964) and extracts were prepared from $\mathrm{r}: 20$ dilutions of the incubated homogenates. The diets were 
extracted by mixing $0.4 \mathrm{~g}$ diet with $4.4 \mathrm{ml} 0.2 \mathrm{M}$-sodium phosphate buffer, $\mathrm{pH} 6 . \mathrm{I}$, and $0.9 \mathrm{ml} \mathrm{I} \%(\mathrm{w} / \mathrm{v})$ ascorbic acid solution, making the volume up to $10 \mathrm{ml}$ with water and autoclaving at $12 \mathrm{I}^{\circ}$ for $\mathrm{I} 5 \mathrm{~min}$.

Haematological methods. Haemoglobin was determined as oxyhaemoglobin and packed cell volume by a micro method. Blood and bone marrow films were stained with Leishman's stain. Total white cells were counted in $I: 20$ dilutions of blood in $\mathrm{I} \%(\mathrm{v} / \mathrm{v})$ acetic acid and differential counts were made on blood films by counting I oo leucocytes. Serum Fe was determined by the method of Bothwell \& Mallett (I955).

\section{RESULTS}

Effects of the diets. In Expt 1 the initial mean body-weight of both the Fe-deficient and the control group was $5^{6} \mathrm{~g}$; after 12 days the average weights were $97 \mathrm{~g}$ in the deficient group and $103 \mathrm{~g}$ in the controls. The respective mean weights of the surviving animals after 26 days were 128 and $143 \mathrm{~g}$, after 40 days $140 \mathrm{~g}$ and $175 \mathrm{~g}$ and after 85 days, I76 g and $208 \mathrm{~g}$. Similar differences in growth rate were recorded in Expt 2.

Table I. Expt I. Haemoglobin, packed cell volume and serum iron in rats after various times on Fe-deficient and Fe-supplemented diets

(Eight rats in each group)

\begin{tabular}{|c|c|c|c|c|c|c|c|c|c|c|c|c|}
\hline \multirow{3}{*}{$\begin{array}{l}\text { Time } \\
\text { on } \\
\text { diet } \\
\text { (days) }\end{array}$} & \multicolumn{4}{|c|}{$\begin{array}{l}\text { Haemoglobin concentration } \\
\qquad(\mathrm{g} / \mathrm{I} 00 \mathrm{ml})\end{array}$} & \multicolumn{4}{|c|}{ Packed cell volume $(\%)$} & \multicolumn{4}{|c|}{$\operatorname{Serum~} \mathrm{Fe}(\mu \mathrm{g} / 100 \mathrm{ml})$} \\
\hline & \multicolumn{2}{|c|}{$\begin{array}{c}\begin{array}{c}\text { Deficient } \\
\text { groups }\end{array} \\
\end{array}$} & \multicolumn{2}{|c|}{$\begin{array}{l}\text { Control } \\
\text { groups }\end{array}$} & \multicolumn{2}{|c|}{$\begin{array}{c}\begin{array}{c}\text { Deficient } \\
\text { groups }\end{array} \\
\text {. }\end{array}$} & \multicolumn{2}{|c|}{$\begin{array}{l}\text { Control } \\
\text { groups }\end{array}$} & \multicolumn{2}{|c|}{$\begin{array}{c}\text { Deficient } \\
\text { groups }\end{array}$} & \multicolumn{2}{|c|}{$\begin{array}{l}\text { Control } \\
\text { groups }\end{array}$} \\
\hline & Mean & SD & Mean & SD & Mean & SD & Mean & SD & Mean & SD & Mean & SD \\
\hline 0 & 13.9 & $I \cdot 3$ & 13.9 & 0.9 & 46 & 2 & 44 & 2 & - & - & - & - \\
\hline 14 & $7 \cdot 4$ & $I \cdot 0$ & $14^{\circ} \circ$ & 0.5 & 22 & 2 & 40 & 3 & 50 & 19 & 248 & 54 \\
\hline 28 & 6.5 & I.9 & $14 \cdot 4$ & 0.1 & 24 & 4 & 44 & 2 & 36 & I9 & 290 & 40 \\
\hline 42 & $5 \cdot 0$ & $1 \cdot 4$ & $14 \cdot 8$ & 0.9 & $2 I$ & 3 & 43 & 4 & - & - & - & - \\
\hline 88 & $5 \cdot 2$ & $1 \cdot 0$ & $14^{\circ} 9$ & 0.9 & 22 & 2 & 44 & 2 & - & - & - & - \\
\hline
\end{tabular}

Marked reductions in haemoglobin, packed cell volume and serum $\mathrm{Fe}$ were noted in the Fe-deficient rats after 14 days (Table r). At the end of Expt 2 the mean haemoglobin concentration in the deficient rats was $3.4 \mathrm{~g} / 100 \mathrm{ml}$ (standard deviation $\mathrm{I} \cdot 3$ ) and in the controls, $14.2 \mathrm{~g} / 100 \mathrm{ml}(\mathrm{SD} \mathrm{r} \cdot 6$ ); the corresponding packed cell volumes were $16 \%$ (SD 5) and $44 \%(\mathrm{SD} 4$ ) and the serum Fe values $44 \mu \mathrm{g} / \mathrm{IO0} \mathrm{ml} \mathrm{(SD} \mathrm{8)} \mathrm{and} 262 \mu \mathrm{g}$ / I00 $\mathrm{ml}$ (SD 20).

Hepatic glutamate formiminotransferase. The activity in several homogenates was not significantly altered by storage for up to 25 days. The coefficient of variation of eighteen results on homogenates from one liver in the same experiment was $5.1 \%$. Nine homogenates from one liver were assayed twice in consecutive experiments; the mean values were 3.86 and 3.95 units $/ g$ and the coefficients of variation $6.7 \%$ and $7.3 \%$ respectively. Enzyme activity was directly proportional to time in the first $3 \mathrm{~min}$. The relationship between activity and the amount of homogenate was non-linear unless the homogenates were diluted at least three times. The Michaelis constant $\left(K_{m}\right)$ for tetrahydropteroylglutamicacid with a crudehomogenate was I $\times 10^{-4}$ moles $/ 1$, 
in agreement with the value for a purified preparation from hog liver (Tabor \& Wyngarden, 1959).

There were no significant differences between the mean concentration of enzyme in the deficient and control groups in Expt I $(P>0.1$ in all instances, Table 2). In Expt 2 the specific activity in the solutions from the deficient and control livers respectively increased from 0.005 to 0.07 units/mg protein and from 0.004 to 0.06 units/mg protein, but the recoveries of enzyme were only $2.4 \%$ and $2 \cdot 9 \%$. The activities in the solutions, including the discarded fractions, from the livers of the two

Table 2. Expt $\mathrm{x}$. Liver glutamate formiminotransferase activity and liver and serum folic acid activity in rats after various times on iron-deficient and iron-supplemented diets

(Eight rats in each group)

\begin{tabular}{|c|c|c|c|c|c|c|c|c|c|c|c|c|}
\hline \multirow{3}{*}{$\begin{array}{c}\text { Time } \\
\text { on diet } \\
\text { (days) }\end{array}$} & \multicolumn{4}{|c|}{$\begin{array}{l}\text { Glutamate formiminotransferase } \\
\text { activity (units/g wet liver) }\end{array}$} & \multicolumn{4}{|c|}{$\begin{array}{l}\text { Liver folic acid activity } \\
(\mu \mathrm{g} / \mathrm{g} \text { wet liver })\end{array}$} & \multicolumn{4}{|c|}{$\begin{array}{l}\text { Serum folic acid activity } \\
(\mathrm{ng} / \mathrm{ml})\end{array}$} \\
\hline & \multicolumn{2}{|c|}{$\begin{array}{c}\text { Deficient } \\
\text { groups }\end{array}$} & \multicolumn{2}{|c|}{$\begin{array}{l}\text { Control } \\
\text { groups }\end{array}$} & \multicolumn{2}{|c|}{$\begin{array}{l}\text { Deficient } \\
\text { groups }\end{array}$} & \multicolumn{2}{|c|}{$\begin{array}{l}\text { Control } \\
\text { groups }\end{array}$} & \multicolumn{2}{|c|}{$\begin{array}{c}\text { Deficient } \\
\text { groups }\end{array}$} & \multicolumn{2}{|c|}{$\begin{array}{l}\text { Control } \\
\text { groups }\end{array}$} \\
\hline & Mean & SD & Mean & SD & Mean & $\mathrm{SD}$ & Mean & SD & Mean & $\mathrm{SD}$ & Mean & SD \\
\hline o & $6 \cdot 34$ & 0.91 & 6.01 & 0.67 & 9.5 & $3 \cdot I$ & $8 \cdot 4$ & $Y \cdot 2$ & - & - & - & - \\
\hline 14 & $5 \cdot 29$ & I.28 & $5 \cdot 67$ & 0.71 & $5 \cdot 9$ & I. 6 & $6 \cdot 1$ & I. 4 & - & - & - & - \\
\hline 28 & $6 \cdot 10$ & 0.83 & 5.99 & 0.62 & $7 \cdot 9$ & $1 \cdot 6$ & $8 \cdot 3$ & $I \cdot 5$ & - & - & 一 & - \\
\hline 42 & $6 \cdot 28$ & 0.93 & $6 \cdot 18$ & 0.58 & $9 \cdot 4$ & $1 \cdot 8$ & $7 \cdot 6$ & 2.5 & 42 & 23 & 39 & 28 \\
\hline 88 & $5 \cdot 52$ & 0.82 & $5 \cdot 78$ & 0.52 & 14 & $2: 7$ & I 2 & $\mathrm{x} \cdot 8$ & 44 & 15 & 45 & I 4 \\
\hline
\end{tabular}

groups were similar at all stages of the purification. When the concentration of either tetrahydropteroylglutamate or formiminoglutamate in the enzyme reaction mixtures was altered, the activity in the final solution from the Fe-deficient livers was similar to that in the corresponding solution from the control livers. A more detailed account of these results is available (Burns, I968). Because of the low recoveries of enzyme, the process was repeated with two other batches of normal rat liver; the recoveries were as low on both occasions.

Folic acid activity. The diet without added folic acid contained $\mathrm{I} 9 \circ \mu \mathrm{g}$ folic acid activity $/ \mathrm{kg}$.

The optimal conditions (Bennett et al. 1964) for the assay of folic acid in rat liver were confirmed. Storage of whole liver at $-18^{\circ}$ for up to 7 days and of incubated homogenates for up to 9 days did not produce any marked change in activity. Nine separate samples were prepared from each of four livers and each batch was assayed in a separate experiment; the coefficients of variation were $7 \cdot 1 \%, 6.0 \%, 7 \cdot 0 \%$ and $6.3 \%$. Extracts from ten livers were assayed in duplicate in consecutive assays; there was no significant difference between the results as tested by the method of paired comparisons.

In Expt $\mathrm{r}$, the mean hepatic folic acid activity of the rats killed after 88 days was somewhat higher than in those killed earlier (Table 2), but there was no significant difference between the mean values for the deficient and control animals at any time $(P>0 \cdot I$ in all instances). There was no significant difference between the serum 
folic acid activity in the deficient and control groups killed on days 42 and 88 in Expt I $(P>0 \cdot 1$, Table 2).

Granulocyte counts and appearance of bone marrow. These studies were only made in Expt 1 . The mean granulocyte count on the deficient and control groups respectively was $\mathrm{I} 429$ granulocytes $/ \mathrm{mm}^{3}$ (SD 590) and $\mathrm{I}_{494}$ (SD 742) after 20 days and $2 \mathrm{I} 20$ (SD 398) and I355 (SD 489) after 33 days. No animal had a granulocyte count below $500 / \mathrm{mm}^{3}$ as reported in folic acid deficiency in the rat (Darke \& White, I950). The bone marrow films from the Fe-deficient rats showed no evidence of megaloblastosis.

\section{DISCUSSION}

The results show no evidence of an adverse effect of Fe deficiency on hepatic glutamate formiminotransferase either in crude preparations from rats on a diet which did not contain added folic acid or in partially purified preparations from rats on the same diet supplemented with folic acid. Crude preparations were used in Expt I because of the losses of enzyme expected during purification, and preliminary tests with such homogenates showed the results to be reproducible. Purification of the enzyme from hog liver caused a loss of over half the activity at the stage to which our preparations were taken (Tabor \& Wyngarden, 1959). No details of the isolation of the enzyme from rat liver were given by Vitale et al. $(1965,1966)$ but they apparently used the same method as in the present work. Under these conditions we lost over $95 \%$ of the enzyme, but the yield was consistent in four separate batches. Thus, the method would require modification in order to improve the yield of enzyme, although considerable purification was obtained.

No differences attributable to Fe deficiency were found in the levels of folic acid activity in liver or serum. The results from serum are consistent with one earlier report (Vitale et al. 1965) but not with another (Vitale et al. 1966). The liver contains the largest amount of folic acid in the body (Grossowicz, Rachmilewitz \& Izak, 1963), so that hepatic folic acid activity may provide a better indication of the folic acid content of the tissues than does serum folate; the earlier workers did not measure folic acid in liver.

No reason is evident for the discrepancies between our results and those described previously. Like the earlier authors, we studied albino rats, but the strains were probably different and we had to use females because of difficulty in obtaining sufficient numbers of males, the sex investigated by Vitale et al. (1966). The diets were different in composition, but both produced severe Fe deficiency and supported growth adequately when supplemented with $\mathrm{Fe}$. Our diet without added folic acid contained at least $190 \mu \mathrm{g}$ folic acid $/ \mathrm{kg}$; the true figure would be higher because the diets were not treated with conjugase before assay. Thus the level was probably less than that in the other authors' diet when supplemented with folic acid but more than in their unsupplemented diet. This is supported by the observation that the serum folate levels in our rats were lower than those found by Vitale et al. (1965) in rats on the supplemented diet but higher than in rats on the unsupplemented diet. It therefore seems unlikely that the conflicting results can be explained by differences in the folic acid content of the diets. 
This study does not cover all aspects of the problem; nevertheless the results seem sufficiently clear to be of interest. We concluded that the phenomenon of deranged folic acid metabolism in Fe deficiency is not reproducible under all conditions and because of this it was decided not to continue the work.

We are grateful to Dr Sheila Callender for examining the bone marrow films; to Dr M. A. Foster of the Microbiology Unit, Department of Biochemistry, University Museum, Oxford, for help with the synthesis of tetrahydropteroylglutamic acid; to Miss Susan Parker and Miss Evelyn Taylor for technical assistance and to Mrs Margaret Gordon for help with the preparation of the diets and the care of the animals.

\section{REFEREN CES}

Bennett, M. C., Berry, V., Chanarin, I. \& Ardeman, S. (1964). F. clin. Path. 17, 27.

Bothwell, T. H. \& Mallett, B. (1955). Biochem. F. 59, 599.

Burns, D. G. (1968). Observations on the effects of iron deficiency and anticonvulsant drugs on folate metabolism in the rat. D. Phil. Thesis, University of Oxford.

Cameron, D. G. \& Watson, G. M. (1948). Blood 3, 292.

Chanarin, I., Rothman, D. \& Berry, V. (1965). Br. med. F. i, 480.

Darke, S. J. \& White, C. (1950). Br. F. Nutr. 4, 9.

Grossowicz, N., Rachmilewitz, M. \& Izak, G. (1963). Proc. Soc. exp. Biol. Med. Ir2, 486.

Layne, E. (1957). In Methods in Enzymology. Vol. 3, p. 45I. [S. P. Colowick and N. O. Kaplan, editors.] New York: Academic Press Inc.

MacDonald, R. A., Jones, R. S. \& Pechet, G. S. (1965). Archs Path. 8o, I53.

McCall, M. G., Newman, G. E., O'Brien, J. R. P., Valberg, L. S. \& Witts, L. J. ( 1962). Br. F. Nutr. 16, 297.

O'Dell, B. L., Vandenbelt, J. M., Bloom, E. S. \& Pfiffner, J. J. (1947). F. Am. chem. Soc. 69, 250.

Spray, G. H. (1964). 7. clin. Path. 17, 660.

Tabor, H. \& Wyngarden, L. (1958). F. clin. Invest. 37, 824.

Tabor, H. \& Wyngarden, L. (I959). F. biol. Chem. 234, I83o.

Velez, H., Restrepo, A., Vitale, J. J. \& Hellerstein, E. E. (1966). Am. F. clin. Nutr. 19, 27.

Vitale, J. J., Restrepo, A., Velez, H., Riker, J. B. \& Hellerstein, E. E. (I966). J. Nutr. 88, 3 I 5.

Vitale, J. J., Streiff, R. R. \& Hellerstein, E. E. (1965). Lancet ii, 393. 